\title{
PENERAPAN MODEL PEMBELAJARAN KOOPERATIF TIPE STUDENT TEAM ACHIEVEMENT DIVISIONS (STAD) UNTUK MENINGKATKAN HASIL BELAJAR IPA SISWA KELAS IV DI SD NO. 1 SEMBUNG KECAMATAN MENGWI TAHUN PELAJARAN 2016/2017
}

\author{
Ayu IraTrisna Dewi ${ }^{1}$, Made Sumantri² \\ 1, 2, 3Jurusan PGSD, FIP \\ Universitas Pendidikan Ganesha \\ Singaraja, Indonesia \\ e.mail : iratrisnadewi18@g.mail.com¹, madesumantri_pgsd@yahoo.co.id²
}

\begin{abstract}
Abstrak
Penelitian ini bertujuan untuk mengetahui peningkatan hasil belajar IPA pada siswa kelas IV di SD No.1 Sembung tahun pelajaran 2016/2017setelah diterapkannya model pembelajaran kooperatif tipe STAD.Jenis penelitian ini adalah penelitian tindakan kelas yang melibatkan subjek sebanyak 16 orang siswa. Objek penelitian ini adalah hasil belajar IPA siswa melalui penerapan model pembelajaran kooperatif tipe STAD. Data hasil belajar siswa diperoleh melalui hasil observasi menggunakan lembar observasi dan data hasil belajar siswa diperoleh menggunakan tes tertulis. Data yang terkumpul selanjutnya dianalisis secara deskriptif.Hasil penelitian menunjukkan bahwa, dengan menggunakan penerapan model pembelajaran kooperatif tipe STAD dapat meningkatkan persentase hasil belajar IPA siswa sebesar $25 \%$, pada siklus I yaitu $68,75 \%$,dan pada siklus II menjadi $93,75 \%$. Berdasarkan hasil dan pembahasan dapat disimpulkan bahwa, hasil belajar IPA siswa meningkat melalui penerapan model pembelajaran kooperatif tipe student teams achievement divisions (STAD) siswa kelas IV SD No. 1 Sembung tahun pelajaran 2016/2017. Disarankan pada guru kelas yang lain, agar bisa menerapkan model pembelajaran tipe student teams achievement division (STAD) ini pada mata pelajaran yang berbeda. Karena penerapan model pembelajaran tipe student teams achievement divisions (STAD) ini terbukti dapat meningkatkan hasil belajar siswa.
\end{abstract}

Kata kunci: penerapan model pembelajaran STAD, dan hasil belajar.

\begin{abstract}
This study aims to determine the learning outcome IPA in the fourth grade students in elementary school year 1 Sembung 2016/2017setelah implementation kooperatif tipe STAD learning model. This research is a classroom action research which involves the subject of as many as 16 students. The object of this study is science student learning outcomes through the implementation of cooperative learning model type STAD. Student learning outcomes data obtained through observation using observation sheet data and student learning outcomes obtained using the written test. Collected data were analyzed descriptively. The results showed that, using the application of cooperative learning model type STAD can increase the percentage of students' science learning outcomes by $25 \%$, in the first cycle is $68.75 \%$, and the second cycle be $93.75 \%$. Based on the results and discussion can be concluded that, IPA increased student learning outcomes through the implementation of cooperative learning model student teams achievement divisions (STAD) fourth grade students of SD No. 1 Sembung the school year 2016/2017. Suggested to the teacher of the class, in order to apply the model of the type of learning is student teams achievement divisions on different subjects. Because the application of learning models of type student teams achievement divisions have proven to improve student learning outcomes.
\end{abstract}

Key words: application of learning models stad, and learning outcomes 


\section{PENDAHULUAN}

Dalam UU RI No. 20 Tahun 2003 (Malik Fajar) Bab 1 Pasal 1 menyatakan bahwa pendidikan adalah usaha sadar dan terencana untuk mewujudkan suasana belajar dan proses pembelajaran agar peserta didik secara aktif mengembangkan potensi dirinya untuk memiliki kekuatan spiritual keagamaan, pengendalian diri, kecerdasan, akhlak mulia, serta keterampilan yang diperlukan dirinya, masyarakat, bangsa dan negara. Dengan demikian, untuk meningkatkan mutu pendidikan perlu mewujudkan suasana belajar dan proses pembelajaran yang berkualitas dengan mengadakan pembaharuan dalam model, metode, pendekatan dan media dalam proses pembelajaran.

Pembelajaran adalah "suatu sistem yang bertujuan untuk membantu proses belajar siswa, yang berisi serangkaian peristiwa yang dirancang, disusun sedemikian rupa untuk mempengaruhi dan mendukung terjadinya proses belajar siswa yang bersifat internal" Gagne dan Briggs (2009). Suatu pengertian yang hampir sama dikemukakan oleh Aisyah, dkk. (2008) bahwa pembelajaran adalah "suatu proses yang berkaitan dengan lingkungan seseorang secara sengaja dikelola untuk memungkinkan ia turut serta dalam kondisikondisi khusus atau menghasilkan respon terhadap situasi tertentu". Dengan demikian, pembelajaran merupakan suatu proses yang dirancang untuk membelajarkan pebelajar

$$
\text { Proses pembelajaran IPA }
$$

merupakan proses interaksi antara peserta didik dengan guru sebagai pengajar. Keberhasilan belajar peserta didik yang dicapai dapat diukur melalui penelitian hasil belajar. Disamping itu keberhasilan dalam kegiatan pembelajaran IPA dipengaruhi oleh banyak faktor satu dari sekian banyak faktor tersebut yaitu menentukan atau memilih pendekatan pembelajaran. Dalam pembelajaran IPA dikaitkan dengan cara mencari tahu tentang gejala alam secara sistematis, sehingga IPA bukan hanya sebagi penguasaan kumpulan pengetahuan yang berupa fakta-fakta, konsep-konsep, atau prinsip-prinsip saja tetapi juga merupakan suatu proses penemuan. Pendidikan IPA diarahkan untuk mencari tahu dan berbuat sehingga dapat membantu peserta didik untuk memperoleh pemahaman yang lebih mendalam tentang alam sekitar. Namun terkadang dalam proses pembelajaran sering terjadi kekeliruan yang dilakukan oleh seorang guru, yaitu mengajarkan IPA dengan cara mentransfer begitu saja apa yang diuraikan dalam buku teks pada anak didiknya. Hal ini disebabkan apa yang tersurat dalam buku teks itu baru merupakan satu dimensi saja dari IPA yaitu dimensi produk. Buku teks baru merupakan body of knowledge dari IPA, merupakan akumulasi hasil upaya printis IPA terdahulu dan umumnya telah tersusun secara lengkap dan sistematis. Meskipun buku teks penting tetapi ada sisi lain dari IPA yang tidak kalah pentingnya yaitu dimensi proses, maksudnya proses mendapatkan atau memperoleh suatu keberhasilan IPA itu sendiri.

IPA diperoleh melalui penelitian dengan menggunakan langkah-langkah tertentu yang disebut metode ilmiah. Untuk itu dalam proses pembelajaran IPA harus menekankan dua aspek agar pembelajaran IPA dapat bermakna dan bermanfaat.Dalam pendekatan keterampilan proses siswa dipandang baik sebagai subjek didik maupun objek didik. Tekanannya pada pengembangan intelektual dan emosional anak didik, sehingga menjadi manusia yang utuh. Pendekatan keterampilan proses mendambakan aktivitas untuk memperoleh informasi dari berbagai sumber (misalnya dari observasi, eksperimen, dan sebagainya) sedangkan guru bertindak sebagai organisator dan fasilitator, dalam suatu kegiatan pembelajaran dapat dikatakan terjadi belajar, apabila terjadi proses perubahan perilaku pada siswa sebagai hasil dari suatu pengalaman. Dari jabaran tersebut, maka dapat di identifikasikan dua aspek penting yang ada dalam kegiatan pembelajaran tersebut. Aspek pertama adalah aspek Hasil belajar 
yakni perubahan perilaku pada siswa. Aspek yang kedua adalah aspek proses belajar yakni sejumlah pengalaman intelektual, emosional, dan fisik pada diri siswa.

Tujuan pokok penyelenggaraan kegiatan pembelajaran ini mengandung makna untuk meletakkan landasan bagi pelajar agar belajar seumur hidup. Tujuan ini harus tercapai, kalau kita ingin memenuhi tuntutan percepatan perubahan yang berlangsung terus menerus. Pada masa sekarang ini bukanlah waktunya lagi bagi guru untuk menjadi orang pertama yang bertindak sebagai komunikator. Adanya berbagai penemuan penelitian menyebabkan fakta, konsep, prinsip sering kali berumur semakin pendek. Oleh kaena itu, tujuan pokok penyelenggaraan kegiatan pembelajaran di sekolah secara oprasional adalah membelajarkan siswa agar mampu memproses dan memperoleh pengetahuan, keterampilan, dan sikap bagi dirinya sendiri. Pengembangan keterampilan proses siswa dapat dilatihkan melalui suatu kegiatan pembelajaran yang menggunakan pendekatan keterampilan proses. Siswa diberi kesempatan untuk terlibat langsung dalam kegiatan-kegiatan ilmiah seperti yang dikerjakan para ilmuwan, tetapi pendekatan keterampilan proses tidak bermaksud menjadikan setiap siswa menjadi ilmuwan. Pembelajaran dengan pendekatan keterampilan proses dilaksanakan dengan maksud karena IPA merupakan alat yang potensial untuk membantu mengembangkan kepribadian siswa. Kepribadian yang berkembang merupakan prasyarat untuk melangkah ke profesi apapun yang diminati siswa.

Di dalam kelas terutama pada pembelajaran IPA kebanyakan siswa tidak mau menghiraukan guru ketika sedang menyapaikan materi bahkan ada siswa yang bercanda dan asik bermain pada waktu pembelajaran berlangsung. Hal ini menunjukkan rendahnya prestasi belajar IPA di SD No. 1 Sembung belum tercapai secara maksimal di kelas IV. Untuk mengatasi permasalahan tersebut maka guru mencoba mencari solusi untuk mengatasinya dengan berbagai kegiatan atau pendekatan. Dari pendekatan tersebut akan memperoleh suatu strategi yang akan mengubah pola pembelajaran yang dulunya berpusat pada guru, dan akan merubah pusat pembelajarannya pada siswa maupun pembelajaran dalam berkelompok.

Model pembelajaran kooperatif adalah "pembelajaran yang secara sadar dan sistematis mengembangkan interaksi yang silih asah, silih asih, dan silih asuh antar siswa sebagai latihan hidup dalam masyarakat nyata" (Nurhadi, dkk. 2004; Nur, 2005; Kuntjojo, 2009). Pembelajaran kooperatif siswa bekerja sama dalam kelompok kecil saling membantu untuk mempelajari suatu materi (Slavin, 2008; Santyasa, 2007; Ibrahim, 2000; Suprijono, 2009). Dalam pembelajaran kooperatif, kelas disusun atas kelompok-kelompok kecil yang terdiri dari 4-5 orang siswa dengan kemampuan yang berbeda. Jadi, pembelajaran kooperatif lebih menekankan pada pembelajaran yang berorientasi pada siswa.

Tipe STAD (Student Teams Achievement Divisions) yang merupakan salah satu model pembelajaran kooperatif (Nurhadi, dkk., 2004; Slavin, 2008; Taniredja, 2011) membagi para siswa di dalam kelas menjadi beberapa kelompok atau tim, masing-masing terdiri atas 4 atau 5 anggota kelompok yang anggotanya heterogen, baik jenis kelamin, ras, etnik, maupun kemampuan (rendah, sedang, dan tinggi). Hal tersebut dapat mengkondisikan suasana lingkungan yang nyaman bagi siswa dalam proses pembelajaran. Hal ini dikarenakan siswa dapat saling bertukar pendapat dengan teman sebayanya, mendiskusikan masalah, dan siswa yang kurang mampu dalam menyelesaikan suatu masalah dapat belajar dari temannya yang lebih mampu dalam satu kelompok.

Berdasarkan hal tersebut, dilakukan penelitian yang berjudul "Penerapan Model Pembelajaran Kooperatif Tipe Student Teams Achievement Divisions (STAD) untuk Meningkatkan Hasil Belajar IPA Siswa Kelas IV Di SD No. 1 Sembung 
Kecamatan Mengwi Tahun Pelajaran 2016/2017".

Berdasarkan latar belakang masalah yang telah diuraikan di atas, masalah yang dikaji dalam penelitian ini adalah sebagai berikut apakah penerapan model pembelajaran kooperatif tipe Student Teams Achievement Divisions (STAD) dapat meningkatkan hasil belajar IPA bagi siswa kelas IV di SD No. 1 Sembung Kecamatan Mengwi tahun pelajaran 2016/2017?

Sesuai dengan rumusan masalah penelitian, tujuan yang hendak dicapai dalam penelitian ini adalah untuk mengetahui peningkatan hasil belajar IPA siswa kelas IV di SD No. 1 Sembung Kecamatan Mengwi tahun pelajaran 2016/2017 setelah diterapkannya model pembelajaran kooperatif tipe Student Teams Achievement Divisions (STAD).

Manfaat yang diperoleh dari penelitian ini, ada dua manfaat yaitu manfaat teoretis dan manfaat praktis.

\section{METODE PENELITIAN}

Jenis penelitian ini adalah penelitian tindakan kelas (PTK) atau Classroom Action Research. PTK memiliki peranan yang sangat penting dan strategis untuk meningkatkan mutu pelajaran melalui suatu tindakan bernakna dengan menggunakan sebuah model atau suatu pendekatan pembelajaran yang diperhitungkan dapat memecahkan masalah atau memperbaiki situasi dan kemudian secara cermat mengamati pelaksanaannya untuk mengukur tingkat keberhasilannya.

Arikunto (2008) mengemukakan bahwa penelitian tindakan kelas adalah penelitian tindakan yang dilakukan dikelas dengan tujuan memperbaiki/meningkatkan mutu praktik pembelajaran. Senada dengan Arikunto, (Wardhani, 2008) mengemukakan bahwa Penelitian Tindakan Kelas (PTK) merupakan penelitian yang dilakukan oleh guru didalam kelas sendirimelalui refleksi diri dengan tujuan memperbaiki kinerja sebagai guru, sehingga hasil belajar siswa menjadi meningkat.
Berdasarkan definisi di atas, dapat disimpulkan bahwa PTK merupakan penelitian yang dilakukan guru di dalam kelas dengan tujuan untuk memperbaiki kinerja dan mutu praktik pembelajaran, sehingga hasil belajar siswa dapat ditingkatkan.

Penelitian ini direncanakan sebanyak 2 siklus, tapi tidak menutup kemungkinan dilanjutkan ke siklus berikutnya apabila belum memenuhi target penelitian. Masing-masing siklus terdiri dari 2 kali pertemuan ditambah 1 kali pertemuan untuk evaluasi belajar siswa.

Sesuai dengan rancangan suatu penelitian tindakan, dalam hal ini dilakukan refleksi awal dan pelaksanaan penelitian yang terdiri atas dua siklus. Setiap siklus terdiri atas empat tahap yaitu: (1) rencana tindakan, (2) pelaksanaan, (3) observasi dan evaluasi, serta (4) refleksi.

\section{Perencanaan Tindakan}

Sesuai dengan permasalahan yang muncul pada refleksi awal, rencana yang akan dilakukan untuk mengatasi permasalahan tersebut adalah sebagai berikut. a) Guru menyamakan persepsi mengenai model Pembelajaran kooperatif tipe student teams achievement divisions (STAD), b) Guru menentukan materi ajar yang akan dikaji, c) Guru menyusun Rencana Pelaksanaan Pembelajaran (RPP) dan LKS yang sesuai dengan model Pembelajaran kooperatif tipe student teams achievement divisions (STAD), d) Menyiapkan media pembelajaran, e) Peneliti menyusun instrumen penelitian berupa lembar observasi dan tes hasil belajar.

\section{Pelaksanaan Tindakan}

Pada tahap pelaksanaan siklus I ini proses pembelajaran mengacu pada rencana pelaksanaan pembelajaran (RPP) yang telah disusun berdasarkan model pembelajaran kooperatif tipe student teams achievement divisions (STAD) untuk meningkatkan hasil belajar IPA. Adapun langkah-langkah yang diambil adalah 
sebagai berikut. 1) Menyampaikan salam pembuka, mengabsensi kehadiran siswa, menyampaikan standar kompetensi, kompetensi dasar dan indikator yang ingin dicapai dalam pembelajaran, mensosialisasikan model pembelajaran yang digunakan yaitu model pembelajaran kooperatif tipe STAD dan tahapan-tahapan yang dialami dalam STAD. 2) Kegiatan Inti, Guru memberikan penjelasan dengan memperagakan dan menanyakan secara singkat tentang materi pelajaran, siswa diorganisasikan dalam kelompok yang beranggotakan 4-5 orang, pembagian kelompok bersifat heterogen baik berdasarkan jenis kelamin, kemampuan (tinggi, sedang, rendah), ras maupun suku, Setiap kelompok melakukan kegiatan membahas materi yang ada dalam LKS dalam waktu tertentu, Masing-masing siswa memiliki tanggung jawab menjawab soal yang menjadi tugasnya, siswa berdiskusi saling bertukar pendapat untuk menyamakan pendapatnya, Guru membimbing kelompok-kelompok belajar siswa yang mengalami kesulitan dalam menyelesaikan tugas, Guru mengumpulkan laporan masing-masing kelompok, Setelah dua kali pertemuan, siswa diberikan tes hasil belajar mengenai materi yang diajarkan dalam pembelajaran. Skor hasil belajar yang diperoleh siswa disumbangkan sebagai skor kelompok, Guru memeriksa jawaban tes hasil belajar siswa kemudian guru menentukan skor kemajuan individu. Skor kemajuan individu ditentukan berdasarkan selisih perolehan skor tes terdahulu dengan skor tes berikutnya. 3) Penutup, Siswa mengumpulkan hasil diskusi kelompok dan menyerahkannya kepada guru, memberitahukan materi pembela jaran yang akan di bahas minggu depan agar siswa dapat mempersiapkan, mempelajari dan membuat ringkasan lebih awal tentang materi yang akan diajarkan, Guru dan siswa mengucapkan salam penutup, Obsevasi/Evaluasi

\section{Refleksi}

Refleksi dilakukan untuk melihat, mengkaji dan mempertimbangkan dampak tindakan yang telah diberikan. Pedoman yang digunakan dalam refleksi ini adalah lembar observasi, pekerjaan LKS siswa, dan evaluasi hasil belajar siswa. Berdasarkan hasil refleksi ini, guru dapat melakukan perbaikan atas kekurangan dalam proses pembelajaran. Kegiatan yang dilakukan pada rencangan refleksi ini adalah pengkajian dan perenungan hasil penilaian terhadap pelaksanaan tindakan tersebut dengan maksud jika terjadi hambatan, akan dicari pemecahan masalahnya untuk direncanakan tindakan pada siklus selanjutnya

Analisis data dalam penelitian ini adalah menggunakan rumus statistik deskriptif.

$$
N A=\frac{S H T}{S M I} \times 100 \%
$$

Keterangan :

$\mathrm{NA}=$ Rata-rata Skor Siswa

SHT = Skor Hasil Tes

SMI = Skor Maksimal Ideal

Kriteria keberhasilan Penelitian Tindakan Kelas (PTK) ini ditunjukkan dengan adanya peningkatan skor hasil belajar IPA. Hasil belajar IPA dikatakan berhasil atau tuntas apabila secara individu memenuhi KKM yaitu 70 dan secara klasikal skor rata-rata kelas pada kategori baik atau 70-84 dari jumlah keseluruhan siswa. Dengan tercapainya kriteria keberhasilan yang telah ditentukan di atas maka penelitian akan dihentikan.

Tabel 1. Kriteria Tingkat Penguasaan Kompetensi pada Mata Pelajaran IPA

\begin{tabular}{ccccc}
\hline No. & $\begin{array}{c}\text { Tingkat } \\
\text { Penguasaan }\end{array}$ & $\begin{array}{c}\text { Nilai } \\
\text { Huruf }\end{array}$ & Predikat & Keterangan \\
\hline 1 & $85 \%-100 \%$ & A & Sangat & Tuntas \\
2 & $70 \%-84 \%$ & B & Baik & Tuntas \\
3 & $55 \%-69 \%$ & C & Baik & Tidak tuntas \\
4 & $40 \%-54 \%$ & D & Cukup & Tidak tuntas \\
5 & $0 \%-39 \%$ & E & Kurang & Tidak tuntas \\
& & & Sangat & \\
& & & Kurang & \\
\hline
\end{tabular}


HASIL PENELITIAN DAN PEMBAHASAN Pelaksanaan pembelajaran di dalam kelas selama ini secara umum telah berlangsung sesuai dengan rencana pembelajaran yang telah disusun sebagai penerapan model pembelajaran kooperatif tipe STAD (Student Teams Achievement Divisions). Penelitian ini dilaksanakan dalam 2 siklus, dimana setiap siklus dilaksanakan dalam 3 kali pertemuan yaitu 2 kali pertemuan untuk pembelajaran dan 1 kali pertemuan untuk tes. Data yang dikumpulkan dalam penelitian ini, yaitu data tentang hasil belajar IPA siswa terhadap pembelajaran yang dilaksanakan. Data yang telah dikumpulkan dianalisis sesuai dengan teknik analisis data yang telah ditetapkan sebelumnya.

Tabel 2. Data Ketuntasan Hasil Belajar Siswa Terhadap Pelajaran IPA Siklus I

\begin{tabular}{|c|c|c|c|c|c|c|}
\hline \multirow{2}{*}{ KS } & \multirow{2}{*}{$\begin{array}{l}\text { Skor } \\
\text { (SHT) }\end{array}$} & \multirow{2}{*}{$\begin{array}{c}N A=S H T \times \\
100 \% \\
\text { SMI }\end{array}$} & \multicolumn{2}{|c|}{$\begin{array}{c}\text { Tingkat } \\
\text { Penguasaan } \\
\text { Kompetensi } \\
\end{array}$} & \multirow{2}{*}{ Ket } & \multirow[t]{2}{*}{ SMI } \\
\hline & & & $\begin{array}{l}\text { Nilai } \\
\text { Huruf }\end{array}$ & Predikat & & \\
\hline 001 & 12 & 60 & C & Cukup & $\begin{array}{c}\text { Tidak } \\
\text { Tuntas }\end{array}$ & 20 \\
\hline 002 & 11 & 55 & C & Cukup & $\begin{array}{l}\text { Tidak } \\
\text { Tuntas }\end{array}$ & 20 \\
\hline 003 & 10 & 50 & D & Kurang & $\begin{array}{l}\text { Tidak } \\
\text { Tuntas }\end{array}$ & 20 \\
\hline 004 & 17 & 85 & A & $\begin{array}{l}\text { Sangat } \\
\text { Baik }\end{array}$ & Tuntas & 20 \\
\hline 005 & 15 & 75 & B & Baik & Tuntas & 20 \\
\hline 006 & 13 & 65 & C & Cukup & $\begin{array}{l}\text { Tidak } \\
\text { Tuntas }\end{array}$ & 20 \\
\hline 007 & 12 & 60 & C & Cukup & $\begin{array}{l}\text { Tidak } \\
\text { Tuntas }\end{array}$ & 20 \\
\hline 008 & 14 & 70 & B & Baik & Tuntas & 20 \\
\hline 009 & 17 & 85 & A & $\begin{array}{l}\text { Sangat } \\
\text { Baik }\end{array}$ & Tuntas & 20 \\
\hline 010 & 15 & 75 & B & Baik & Tuntas & 20 \\
\hline 011 & 14 & 70 & B & Baik & Tuntas & 20 \\
\hline 012 & 15 & 75 & B & Baik & Tuntas & 20 \\
\hline 013 & 13 & 65 & C & Cukup & $\begin{array}{l}\text { Tidak } \\
\text { Tuntas }\end{array}$ & 20 \\
\hline 014 & 10 & 50 & C & Cukup & $\begin{array}{l}\text { Tidak } \\
\text { Tuntas }\end{array}$ & 20 \\
\hline 015 & 14 & 70 & B & Baik & Tuntas & 20 \\
\hline 016 & 16 & 80 & B & Baik & Tuntas & 20 \\
\hline
\end{tabular}

Keterangan:

$\mathrm{KS}=$ Kode Siswa

NA = Rata-rata Skor Siswa

SHT = Skor Hasil Tes

SMI = Skor Maksimal Ideal
Tabel 3. Data Ketuntasan Hasil Belajar Siswa Terhadap Pelajaran IPA Siklus II

\begin{tabular}{|c|c|c|c|c|c|c|}
\hline \multirow[t]{2}{*}{ KS } & \multirow{2}{*}{$\begin{array}{l}\text { Skor } \\
\text { (SHT) }\end{array}$} & \multirow{2}{*}{$\begin{array}{l}\text { NA }=\text { SHT } \\
\times 100 \% \\
\text { SMI }\end{array}$} & \multicolumn{2}{|c|}{$\begin{array}{c}\text { Tingkat } \\
\text { Penguasaan } \\
\text { Kompetensi }\end{array}$} & \multirow{2}{*}{ Ket } & \multirow[t]{2}{*}{ SMI } \\
\hline & & & $\begin{array}{c}\text { Nilai } \\
\text { Huru } \\
f\end{array}$ & $\begin{array}{c}\text { Predika } \\
t\end{array}$ & & \\
\hline 001 & 15 & 75 & $B$ & Baik & $\begin{array}{c}\text { Tunta } \\
\mathrm{s}\end{array}$ & 20 \\
\hline 002 & 13 & 65 & $\mathrm{C}$ & Cukup & $\begin{array}{c}\text { Tidak } \\
\text { Tunta } \\
\text { s }\end{array}$ & 20 \\
\hline 003 & 14 & 70 & B & Baik & $\begin{array}{c}\text { Tunta } \\
\mathrm{s}\end{array}$ & 20 \\
\hline 004 & 20 & 100 & $A$ & $\begin{array}{c}\text { Sangat } \\
\text { Baik }\end{array}$ & $\begin{array}{c}\text { Tunta } \\
\mathrm{s}\end{array}$ & 20 \\
\hline 005 & 16 & 80 & $B$ & Baik & $\begin{array}{c}\text { Tunta } \\
\text { S }\end{array}$ & 20 \\
\hline 006 & 15 & 75 & $B$ & Baik & $\begin{array}{c}\text { Tunta } \\
\text { s }\end{array}$ & 20 \\
\hline 007 & 14 & 70 & B & Baik & $\begin{array}{c}\text { Tunta } \\
\text { S }\end{array}$ & 20 \\
\hline 008 & 16 & 80 & B & Baik & $\begin{array}{c}\text { Tunta } \\
\text { S }\end{array}$ & 20 \\
\hline 009 & 19 & 95 & $A$ & $\begin{array}{c}\text { Sangat } \\
\text { Baik }\end{array}$ & $\begin{array}{c}\text { Tunta } \\
\text { S }\end{array}$ & 20 \\
\hline 010 & 16 & 80 & $B$ & Baik & $\begin{array}{c}\text { Tunta } \\
\mathrm{S}\end{array}$ & 20 \\
\hline 011 & 16 & 80 & $B$ & Baik & $\begin{array}{c}\text { Tunta } \\
\text { S }\end{array}$ & 20 \\
\hline 012 & 17 & 85 & $A$ & $\begin{array}{l}\text { Sangat } \\
\text { Baik }\end{array}$ & $\begin{array}{c}\text { Tunta } \\
\mathrm{s}\end{array}$ & 20 \\
\hline 013 & 14 & 70 & B & Baik & $\begin{array}{c}\text { Tunta } \\
\text { S }\end{array}$ & 20 \\
\hline 014 & 14 & 70 & B & Baik & $\begin{array}{c}\text { Tunta } \\
\text { s }\end{array}$ & 20 \\
\hline 015 & 15 & 75 & B & Baik & $\begin{array}{c}\text { Tunta } \\
\text { S }\end{array}$ & 20 \\
\hline 016 & 18 & 90 & $A$ & $\begin{array}{c}\text { Sangat } \\
\text { Baik }\end{array}$ & $\begin{array}{c}\text { Tunta } \\
\text { S }\end{array}$ & 20 \\
\hline
\end{tabular}

Keterangan:

$\mathrm{KS}=$ Kode Siswa

NA = Rata-rata Skor Siswa

SHT = Skor Hasil Tes

SMI = Skor Maksimal Ideal 


\section{PEMBAHASAN}

Berdasarkan hasil penelitian di atas, hasil belajar IPA siswa pada akhir siklus I, diperoleh persentase secara klasikal sebesar 68,75 \%. Hasil yang diperoleh ini tentu saja belum memenuhi target yang diharapkan, yaitu kategori siswa cukup. Untuk itu, perlu dilakukan perbaikanperbaikan dalam pelaksanaan pembelajaran yang sesuai dengan kekurangan maupun kendala-kendala yang ditemukan pada pelaksanaan pada pembelajaran pada siklus I.

Dilihat dari hasil refleksi terhadap pelaksanaan tindakan pada siklus I, terlihat adanya berbagai kekurangan maupun kendala-kendala yang muncul dalam proses pelaksanaannya. Kendala-kendala tersebut disebabkan oleh beberapa hal yaitu: (1) siswa belum terbiasa berdiskusi dalam menyelesaikan tugas yang diberikan. Hal ini disebabkan oleh kebiasaan siswa yang hanya sebagai pendengar dan pencatat selama proses pembelajaran. Faktor lain yang juga berpengaruh terhadap antusiasme siswa dalam berdiskusi adalah karena satu sama lain merasa bukan teman dekatnya. (2) siswa belum terbiasa dalam melaksanakan diskusi maupun tanya jawab dan masih malu untuk bertanya. (3) siswa masih memiliki sifat egosentris dan merasa dirinya lebih baik dari temannya. (4) tidak semua siswa turut aktif dalam mengerjakan tugas yang diberikan dan mereka cenderung hanya mengandalkan seorang temannya untuk mengerjakan tugas tersebut. (5) siswa belum terbiasa dalam membuat simpulan yang sistematis sehingga siswa masih membutuhkan bantuan guru dalam membuat simpulan.

Bertolak dari kekurangan-kekurangan yang dihadapi pada siklus I, akan diadakan perbaikan tindakan untuk selanjutnya diterapkan pada siklus II. Perbaikan tindakan yang dilakukan adalah: (1) memberikan motivasi kepada siswa untuk selalu bekerjasama dalam kelompoknya masing-masing, dan mengingatkan penghargaan kelompok diberikan kepada kelompok yang hasil skornya paling tinggi berdasarkan jumlah skor individu setiap masing-masing kelompok. (2) memberikan sedikit arahan atau teguran kepada siswa yang tidak menghargai pendapat temannya sehingga tidak mengganggu proses pembelajaran. (3) mengarahkan siswa dalam membuat simpulan dengan memberikan pertanyaan pancingan yang mengarah pada simpulan yang diharapkan. Dalam diskusi kelas, setiap siswa diberikan kesempatan untuk menanggapi simpulan temannya. Agar siswa tidak mengalami kesalahpahaman terhadap konsep yang telah dipelajari, guru memberikan penegasan.

Berdasarkan implementasi rancangan pada siklus II yang merupakan perbaikan tindakan pada siklus I, memberikan peningkatan hasil yang signifikan. Dari tes hasil belajar IPA pada akhir siklus II, diperoleh hasil persentase secara klasikal sebesar 93,75\%. Kategori hasil belajar siswa mengalami peningkatan dari cukup pada siklus I menjadi sangat baik pada siklus II.Dengan demikian, secara klasikal hasil belajar IPA sudah sesuai dengan kriteria yang diharapkan, yaitu ketuntasan klasikal minimal $70 \%$ dan individu $55 \%$.

Terjadinya peningkatan hasil belajar IPA dikarenakan siswa sudah terbiasa dengan model pembelajaran yang telah diterapkan oleh guru dan sebagian besar siswa telah serius dalam diskusi kelompok, sehingga diskusi dalam kelompok dapat berjalan dengan lancar.

Secara umum, pada pelaksanaan tindakan siklus II tidak lagi muncul kendalakendala seperti pada siklus I. Siswa sudah terbiasa dan telah terlatih belajar dengan mengikuti penerapan model pembelajaran kooperatif tipe $S T A D$. Hal ini terlihat dari kegiatan yang dilakukan siswa telah menunjukkan keterampilan sosial yang diharapkan seperti siswa sudah antusias dalam mengikuti pembelajaran yang dilaksanakan, sudah saling membantu antar anggota kelompok, serius dalam diskusi kelompok, berani mengajukan pertanyaan, mengemukakan pendapat dan menanggapi temannya. Dengan tercapainya keterampilan sosial seperti yang telah 
disebutkan di atas, tentunya hal ini menyebabkan hasil belajar IPA meningkat dari siklus sebelumnya. Walaupun salah satu siswa masih berada dalam kategori kurang, hal ini dikarenakan siswa tersebut kurang lancar dalam membaca yang merupakan modal utama dalam mengikuti proses pembelajaran sehingga siswa tersebut mengalami kesulitan dalam mengerjakan soal-soal individu yang berdampak pada hasil belajar siswa tersebut kurang maksimal.

Dari paparan di atas, secara umum telah mampu menjawab rumusan masalah. Penelitian ini dapat dikatakan berhasil, karena semua kriteria yang ditetapkan telah terpenuhi. Jadi, dapat disimpulkan bahwa penerapan model pembelajaran kooperatif tipe Student Teams Achievement Divisions (STAD) dapat meningkatkan hasil belajar IPA siswa kelas IV SD No. 1 Sembung Kecamatan Mengwi tahun pelajaran 20016/2017.

\section{PENUTUP}

Penerapan model pembelajaran kooperatif tipe STAD telah berhasil meningkatkan hasil belajar IPA siswa kelas IV semester ganjil di SD No. 1 Sembung Kecamatan Mengwi tahun pelajaran 2016/2017. Hal ini dapat dilihat dari persentase hasil belajar IPA siswa kelas IV pada siklus I yaitu $68,75 \%$ kemudian pada siklus II yaitu 93,75\%. Jadi Persentase hasil belajar IPA meningkat $25 \%$.

Berdasarkan simpulan di atas, ada tiga saran yang disampaikan adalah sebagai berikut.

1) Bagi guru sekolah dasar diharapkan mencoba penerapan model pembelajaran kooperatif tipe STAD pada mata pelajaran IPA, karena dapat meningkatkan hasil belajar siswa. 2) Bagi sekolah dapat dijadikan pedoman dalam pembelajaran IPA. 3) Bagi pembaca/calon peneliti yang berminat untuk mengadakan penelitian lebih lanjut tentang penerapan model pembelajaran kooperatif tipe STAD.

\section{DAFTAR RUJUKAN}

Aisyah, Nyimas, dkk. 2008. Pengembangan Pembelajaran SD. Direktorat Jendral Pendidikan Tinggi Departemen pendidikan Nasional.

Arikunto,S,dkk.2008. Penelitian Tindakan Kelas. Jakarta: Bumi Aksara.

Gagne dan Briggs. 2009. "Pengertian Pembelajaran". Tersedia pada http://blog.persimpangan.com/blog

Ibrahim, M, dkk. 2000. Pembelajaran Kooperatif. Surabaya: University Press

Kuntjojo. 2009. Model Pembelajaran Kooperatif. Tersedia pada http://ebekunt.wordpress.com/2009/07 /31/untitled/ (diakses tanggal 5 Oktober 2016).

Nur, Mohamad. 2005. Pembelajaran Kooperatif. Surabaya: Allyn and Bacon

Nurhadi, dkk. 2004. Pembelajaran Kontekstual dan Penerapannya dalam KBK. Surabaya: Universitas Negeri Malang.

Santyasa, Wayan. 2007. Model-Model Pembelajaran Inovatif. Makalah disajikan dalam pelatihan tentang Penelitian Tindakan Kelas bagi GuruGuru SMP dan SMA di Nusa Penida, Nusa Penida 29 Juni s.d 1 Juli 2007.

Slavin, Robert E. 2008. Cooperative Learning (Teori, Riset dan Praktik). Bandung: Nusa Media.

Suprijono, Agus. 2009. Cooperative Learning (Teori \& Aplikasi PAIKEM). Yogyakarta:Pustaka Palajar

Taniredja, Tukirman, dkk. 2012. ModelModel Pembelajaran Inovatif. Bandung:Alfabeta

Undang-Undang RI Nomor 20 Tahun 2003 Tentang Sistem Pendidikan Nasional. jakarta: Sinar Grafika

Wardhani, I. G. A. K. dkk. 2007. Teknik Menulis Karya IImiah. Jakarta: Penerbit Universitas Terbuka. 